PERM JOURNAL OF PETROLEUM AND MINING ENGINEERING

ВЕСТНИК ПНИПУ. ГЕОЛОГИЯ. НЕФТЕГАЗОВОЕ И ГОРНОЕ ДЕЛО

ISSN 2224-9923

Volume/ Toм 16 №2, 2017

http://vestnik.pstu.ru/geo/

УДК 66.063 .12

Article / Статья

(C) PNRPU / ПНИПУ, 2017

\title{
STUDY OF INFLUENCE OF DEMULSIFIERS ON COMPLEX IN RHEOLOGY OIL DEHYDRATION KINETICS
}

\section{Gafar G. Ismaiylov, Esen I. Izbasarov ${ }^{1}$, Mekhpara B. Adygezalova, Ruslan Z. Khalilov}

Azerbaijan State Oil and Industrial University (20 Azadlyg av., Baku, AZ1010, Republic of Azerbaijan)

${ }^{1}$ KazNIPImunaigaz JSC $\left(26^{\text {th }}\right.$ district, Aktau, 130000, Republic of Kazakhstan)

\section{ИССЛЕДОВАНИЕ ВЛИЯНИЯ РЕАГЕНТОВ-ДЕЭМУЛЬГАТОРОВ НА КИНЕТИКУ ОБЕЗВОЖИВАНИЯ РЕОЛОГИЧЕСКИ СЛОЖНОЙ НЕФТИ}

\section{Г.Г. Исмайылов, Е.И. Избасаров ${ }^{1}$, М.Б. Адыгезалова, Р.3. Халилов}

Азербайджанский государственный университет нефти и промышленности (AZ1010, Азербайджан, г. Баку, пр. Азадлыг, 20)

${ }^{1} \mathrm{AO}$ «КазНИПИмунайгаз» (130000, Республика Казахстан, г. Актау, 6-й микрорайон, д. 2)

Received / Получена: 14.03.2017. Accepted / Принята: 15.05.2017. Published / Опубликована: 30.06 .2017

\section{Key words:}

oil treatment, water, water-oil emulsion, viscosity, density, chemical agents, dehydration, demulsifier, surface active agent, kinetics, chloride salts, rheological properties, physical and chemical properties, chemical composition, efficient dosage, agent consumption.
Ключевые слова: подготовка нефти, вода, водонефтяная эмульсия, вязкость, плотность, химические реагенты, обезвоживание, деэмульгатор, поверхностно-активное вещество, кинетика, хлористые соли, реологические свойства, физико-химические свойства, химический состав, эффективная дозировка, расход реагента.
One of the relevant challenges in development of oil fields is a challenge to increase efficiency of oilfield treatment of hydrocarbons. Solution for that challenge can significantly improve level of oil treatment, reduce hydrocarbon losses with drainage water and thereby improve ecology of the environment and make additional profit for an enterprise. A system of gathering and treatment of water and oil of Karazhanbas field, influence of surface active agents (surfactants) on water-oil emulsions under conditions of the field are studied in the paper. In addition, a chemical demulsifier which has the most efficient properties for field treatment of well production at Karazhanbas field is chosen. Results of laboratory studies of water-oil emulsion, physical and chemical analysis of water composition and new chemical demulsifiers, recommended for pilot tests at Karazhanbas field, are presented. Analisys of results of laboratory studies shows that all test chemicals are inferior to a base demulsifier Randem-2208 by a degree of dehydration. Base demilsifier is inferior to demulsifiers Victory2,3 and Rauan-2050 by a degree of desaltation. It is established that demulsifier Victory- 1 in comparison with base and other demulsifiers does not show a high demulsifying ability. In coparison with base Randem-2208 demulsifier Victory-2 showed the lowest demulsifying ability with degree of dehydration equal to $60.67 \%$. In comparison with the base product Randem-2208 demulsifier Victory-3 provides quite good dehydration. Compared to base demulsifier Randem-2208 demulsifier Rauan-2050 has a good demulsifying ability, consumption of demulsifier decreases with increase in water saturation in oil. At the same time, goal-based increase in water saturation of prepeared rheologically complex oil to its ultimate value allows to reduce consumption of demulsifier in several times with no reduce in efficiency oil dehydrationl.

Одной из актуальных проблем разработки нефтяных месторождений является повышение эффективности нефтепромысловой подготовки углеводородов. Решение этой проблемы может значительно повысить степень подготовки нефти, уменьшить потери углеводородов с дренажной водой, тем самым улучшить экологию окружающей среды и принести дополнительную прибыль предприятию. В работе были изучены система сбора и подготовки воды и нефти месторождения Каражанбас, влияние поверхностно-активных веществ (ПАВ) на водонефтяные эмульсии в условиях данного месторождения. Кроме того, был избран химический реагент-деэмульгатор, имеющий наиболее эффективные свойства для промысловой подготовки продукции скважин месторождения Каражанбас. Приведены результаты лабораторных исследований водонефтяной эмульсии, физико-химического анализа состава воды, новых химических реагентов-деэмульгаторов, рекомендуемых для опытно-промысловых испытаний на месторождении Каражанбас. Анализируя результаты лабораторных исследований, можно сделать вывод, что по степени обезвоживания все испытуемые химические реагенты уступают базовому реагенту-деэмульгатору «Рандем-2208», а по обессоливаюшим свойствам базовый деэмульгатор уступает деэмульгаторам марки «Victory-2, 3» и «Rauan-2050». В ходе анализа установлено, что деэмульгатор марки «Victory-1» по сравнению с базовым и другими деэмульгаторами не проявляет высокую деэмульгирующую способность. Деэмульгатор марки «Victory-2» по сравнению с базовым «Рандем-2208» показал наименьшую деэмульгирующую способность, степень обезвоживания составляет 60,67 \%. Деэмульгатор «Victory-3» по сравнению с базовым продуктом «Рандем-2208» обеспечивает достаточно хорошее обезвоживание. У деэмульгатора марки «Rauan-2050» по сравнению с базовым деэмульгатором «Рандем-2208» хорошая деэмульгирующая способность, с ростом водонасыщенности нефти его расход уменьшается. При этом путем целенаправленного повышения водонасыщенности подготовленной реологически сложной нефти до предельного ее значения можно в несколько раз уменьшить расход деэмульгатора, не снижая при этом эффективность процесса обезвоживания нефти.

Gafar G. Ismaiylov - Doctor of Technical Sciences, Professor at the Department of Oil and Gas Transportation and Storage (tel.: +994 50 644 40 06, e-mail: q.ismaylov@asoiu.edu.az). Esen I. Izbasarov - doctorate student (tel.: +994 5064440 06, e-mail: Izbasarov_E@kaznipi.kz).

Mekhpara B. Adygezalova (Author ID in Scopus: 50160952800) - PhD in Chemical Sciences, Associate Professor at the Department of Chemistry and Technology of Inorganic Matter (tel.: +994 7036565 90, e-mail: mehpareadigozelova@yahoo.com). The contact person for correspondence.

Ruslan Z. Khalilov - doctorate student at the Department of Oil and Gas Transportation and Storage (tel.: +994 55 221 20 94, e-mail: ruslan.khalilov@bakerhughes.com).

Исмайылов Гафар Гуламгусейн - доктор технических наук, профессор кафедры транспорта хранения нефти и газа (тел.: +994 50 644 40 06, e-mail: q.ismaylov@asoiu.edu.az). Избасаров Есен Исламбердиевич - докторант (тел.: +994 5064440 06, e-mail: Izbasarov E@kaznipi.kz).

Адыгезалова Мехпара Бабаверди кызы - кандидат химических наук, доцент кафедры химии и технологии неорганических веществ (тел.: +994 703656590 , e-mail: mehpareadigozelova@yahoo.com). Контактное лицо для переписки.

Халилов Руслан Закир - докторант кафедры транспорта хранения нефти и газа (тел.: +994 55221 20 94, e-mail: ruslan.khalilov@bakerhughes.com). 


\section{Introduction}

The challenge of increase in efficiency of field treatment of oil is on the front barrier to overcome because that could significantly increase the efficiency of field treatment of oil, decrease hydrocarbon losses along with drainage water and, thereby, improve the ecology of the environment and bring additional profit to an enterprise [1-7].

As is known, field treatment of oil, its demulsification are carried out under the influence of temperature. Oil is heated and a chemical agent is supplied [8-14]. The higher the temperature the lower the viscosity of oil and the bigger the difference in densities of water and oil. Temperature of demulsification depends on properties of oil and conditions of a process itself. A combined effect of temperature and chemical agent initiate coalescence, i.e. intensive fusion of water droplets into larger ones, capable of falling off quickly and separating themselves from oil under the action of gravity. In laboratory experiments the influence of main factors such as temperature, concentration of agents, amount of stirring and settling time were studied carefully.

\section{Challenge statement}

A technological method of demulsification intends to ensure production of maximum amount of dehydrated oil with lowest irreducible water saturation and with a minimum consumption of a demulsifier. All mentioned should be achieved under considered conditions of economical consumption of fuel and steam, safety of equipment and equipment of an installation. Since increased temperature increases fuel consumption, reduces capacity of an installation and increases loss of valuable light fractions the process should be carried out economically with slight heating of an emulsion. However, the heating value should ensure demulsification process at a sufficient rate [15-25].

\section{Solution for the challenge}

As is known, water-oil emulsions belong to typical representatives of complex heterogeneous and polydisperse systems. Recent studies have shown that in addition to basic physical and chemical property such as viscosity emulsions are also characterised by water saturation [26-28]. In particular, studies of rheological characteristics of artificially created emulsions based on highviscosity anomalous oil of Muradkhanly field on a rotational Rheotest-2 viscometer at temperatures of $20,40{ }^{\circ} \mathrm{C}$ showed that from 22 to $80 \%$ of water saturation system viscosity, as expected, increases with increasing water cut (Fig. 1, $a, b$ ). As can be seen from these figures complete saturation of oil with water occurs at $80 \%$ of water content.
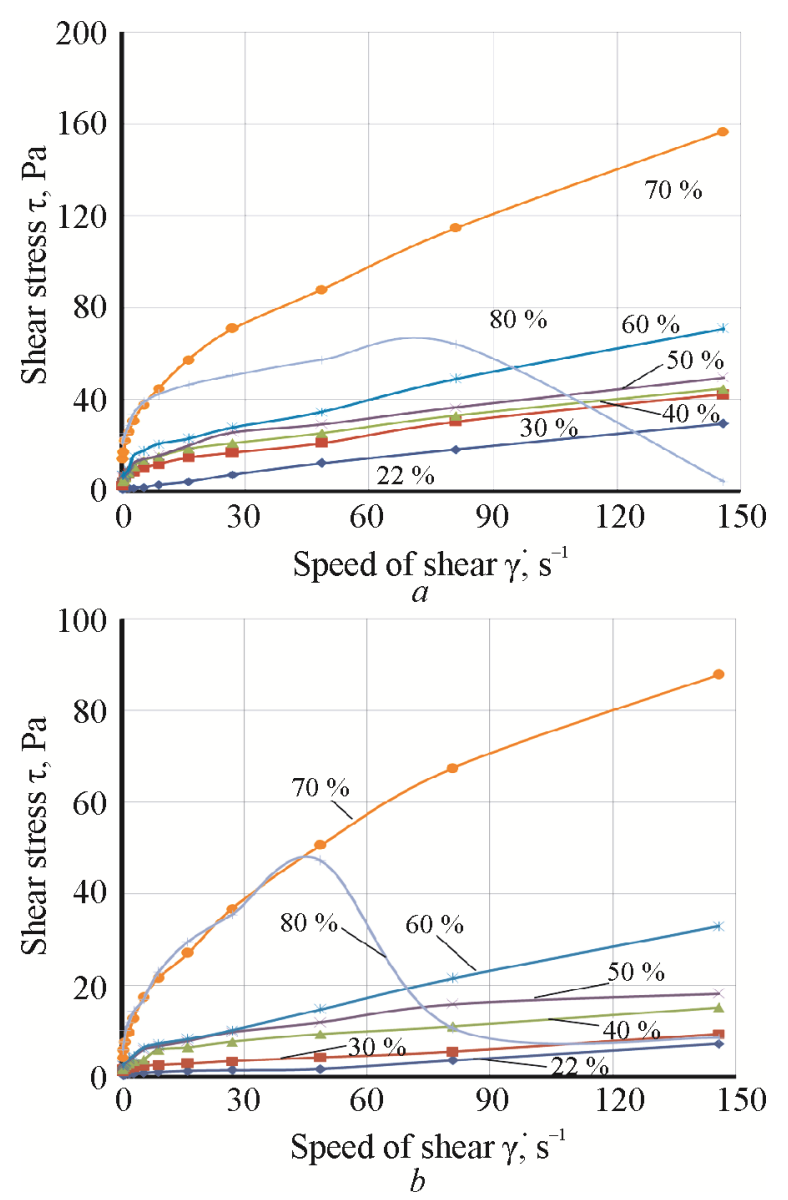

Fig. 1. Graphs of a function of shear stress versus shear speed during flow of Muradkhanly oil at different water content such as

$$
a-T 20^{\circ} \mathrm{C} ; b-T 40^{\circ} \mathrm{C}
$$

There are on oil fields of Azerbaijan foreign demulsifier "Disolvan" (Switzerland) and the domestic "Alcan" were widely used.

Technical documentation regulates high efficiency of these agents. However, usually in 
field conditions real efficiency of mentioned demulsifiers is much lower than the regulated one. That is caused by the fact that at the stage of development and production of agents it is extremely difficult to take into account all the factors that affect their efficiency due to changes in the composition and water saturation of oil produced.

Demulsifying agents Victory-1, 2, 3, Rayan2050, Randem-2208 of Karazhanbasmunai JSC intended for application at facilities of production, collection, treatment and transportation of crude hydrocarbon were tested in laboratory conditions. Demulsifiers of Victory are multi-type, suitable for destruction of various types of water-oil emulsions. They are composite based on surfactants dissolved in organic solvents. The test demulsifier Rauan-2050 is a composite based on block copolymers of ethylene oxide and propylene dissolved in organic solvents and is intended for dehydration and desalting of oil emulsions during collection and treatment of oil in fields. The demulsifier was developed by RauanNalko TOO and is produced according to ST TOO 7585-1915-38-36-2012.

Efficiency of demulsifiers was determined according to a method of ST AO 000840001829 04-14 The method for conducting laboratory tests to assess demulsifying activity of chemical agents by bottle test method [29], the essence of which is visual observation of emulsion stratification and water separation in glass vessels (bottles-sedimentation tanks). The investigated product was added in various dosages into a water-oil emulsion, poured into 100-millimeter settling tanks. Then dynamics of water separated from the emulsion were recorded. To assess stability of an emulsion under study, the experiment includes a dummy experiment in which an emulsion is treated under the same conditions without addition of a demulsifier. Testing of demulsifiers was carried out using a water-oil emulsion of the Karazhanbas field at temperature of $90{ }^{\circ} \mathrm{C}$. At the end of the tests the content of chloride salts in oil was determined by titrating the water extract in accordance with GOST 21534-76 [30].

Dehydration degree of demulsifier was calculated by the formula

$$
P=\frac{V_{1}}{V} 100 \%,
$$

where $V_{1}$ is volume of water, separated after thermostat control, $\% ; V$ is content of bound water in a sample, $\%$.

The effective dosage was determined according to the following criteria:

- approximate (indicative) assessment of efficiency at specific consumptions 150, 200, 240, $300 \mathrm{~g} /$ tonne;

- clarification of the optimal effective dosage of a demulsifier at specific consumption 220-260 g/tonne.

Tables 1-5 and Fig. 2-7 show results of study of kinetics of water coming of the test demulsifiers under conditions of Karazhanbas field. The analysis of laboratory studies has shown that oil of the field taken from a well and gas-measuring unit is homogenious, similar in chemical composition and properties. Oil relates to a paraffin-type (average $3.7 \%$ by weight), high-resin (average $19 \%$ by weight), high-sulfur and in terms of chloride salts and mechanical impurities belong to the third group.

Since demulsifier Randem-2208 is already used at facilities of the Karazhanbas field, it is considered as the basic one and is an agent-demulsifier for comparison. Based on results of tests (Table 1 and Fig. 2), it is obvious that there is no adverse effect on the process of treatment, dehydration and desalting of oil during adding into the initial wateroil emulsion of amount of $240 \mathrm{~g} /$ tonne. Dehydration level is $63.27 \%$, residual content of chloride salts is $2.44 \mathrm{~g} / 1$

Results of the study (Table 2 and Fig. 3) show that Victory-1 demulsifier during adding into a water-oil emulsion of the Karazhanbas field does not show a high demulsibility in comparison with other sorts of Victory demulsifiers. Maximum specific consumption of $300 \mathrm{~g} /$ tone corresponds to 
Table 1

Results of study of kinetics of approximate and specified effective dosage of Randem-2208 demulsifier at $90{ }^{\circ} \mathrm{C}$ of test temperature

\begin{tabular}{|c|c|c|c|c|c|c|c|c|c|c|c|c|c|c|c|c|}
\hline \multirow[b]{3}{*}{ No } & \multirow[b]{3}{*}{ Product } & \multirow{3}{*}{ 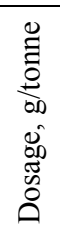 } & \multicolumn{11}{|c|}{ Amount of water released, $\%$} & \multirow{3}{*}{ 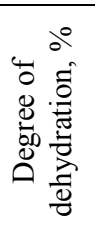 } & \multirow{3}{*}{ 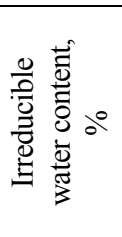 } & \multirow{3}{*}{ 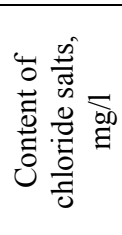 } \\
\hline & & & \multicolumn{11}{|c|}{ Time, $\min$} & & & \\
\hline & & & 5 & 10 & 15 & 20 & 30 & 40 & 50 & 60 & 75 & 90 & 120 & & & \\
\hline \multicolumn{17}{|c|}{ Estimated effectiveness, a value of bound water is $44,6 \%$} \\
\hline 1 & Dummy sample & 0 & 0.00 & 0.00 & 0.00 & 0.00 & 0.00 & 0.41 & 0.82 & 0.82 & 1.64 & 3.28 & 4.10 & 9.19 & 90.81 & 8090.9 \\
\hline 2 & Randem-2208 & 150 & 0.00 & 2.46 & 12.30 & 18.04 & 22.14 & 22.96 & 23.78 & 24.60 & 26.24 & 27.06 & 27.06 & 60.67 & 39.33 & 2764.2 \\
\hline 3 & Randem-2208 & 200 & 0.00 & 3.90 & 11.70 & 17.16 & 22.62 & 22.62 & 23.40 & 24.18 & 24.96 & 25.74 & 25.74 & 57.71 & 42.29 & 2976.3 \\
\hline 4 & Randem-2208 & 240 & 0.00 & 2.49 & 12.45 & 20.75 & 24.90 & 26.56 & 27.39 & 27.39 & 28.22 & 28.22 & 28.22 & 63.27 & 36.73 & 2436.7 \\
\hline 5 & Randem-2208 & 300 & 0.00 & 3.20 & 13.60 & 19.20 & 22.40 & 24.80 & 25.60 & 26.40 & 27.20 & 27.20 & 27.20 & 60.99 & 39.01 & 2648.1 \\
\hline \multicolumn{17}{|c|}{ Specified efficiency, a value of bound water is $42 \%$} \\
\hline 1 & Dummy sample & 0 & 0,00 & 0.00 & 0.00 & 0.00 & 0.00 & 0.80 & 0.80 & 0.80 & 1.20 & 1.60 & 2.40 & 5.71 & 94.29 & 13045.9 \\
\hline 2 & Randem-2208 & 220 & 0.00 & 8.00 & 13.60 & 16.00 & 19.20 & 21.60 & 22.40 & 22.40 & 22.40 & 23.20 & 24.00 & 57.14 & 42.86 & 6319.1 \\
\hline 3 & Randem-2208»» & 260 & 0.00 & 8.20 & 13.94 & 17.22 & 20.50 & 22.14 & 22.96 & 23.78 & 24.60 & 24.60 & 25.01 & 59.55 & 40.45 & 6664.6 \\
\hline
\end{tabular}

Table 2

Results of study of kinetics of approximate and specified effective dosage of Victory-1 demulsifier at $90{ }^{\circ} \mathrm{C}$ of test temperature (a value of bound water is $55.6 \%$ )

\begin{tabular}{|c|c|c|c|c|c|c|c|c|c|c|c|c|c|c|c|c|}
\hline \multirow{3}{*}{ No } & \multirow{3}{*}{ Product } & \multirow{3}{*}{ 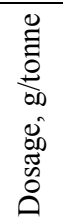 } & \multicolumn{11}{|c|}{ Amount of water released, \% } & \multirow{3}{*}{ 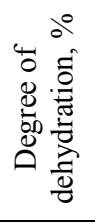 } & \multirow{3}{*}{ 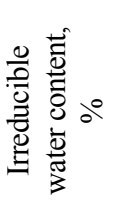 } & \multirow{3}{*}{ 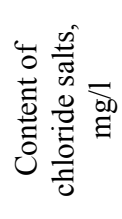 } \\
\hline & & & \multicolumn{11}{|c|}{ Time, $\min$} & & & \\
\hline & & & 5 & 10 & 15 & 20 & 30 & 40 & 50 & 60 & 75 & 90 & 120 & & & \\
\hline 1 & Dummy sample & 0 & 0.00 & 0.00 & 0.00 & 0.00 & 0.00 & 0.00 & 0.00 & 0.00 & 0.00 & 0.80 & 3.20 & 5.76 & 94.24 & 5940.9 \\
\hline 2 & Victory-1 & 150 & 0.00 & 0.00 & 0.08 & 1.60 & 4.80 & 7.20 & 8.00 & 10.40 & 12.80 & 15.20 & 18.40 & 33.09 & 66.91 & 3193.5 \\
\hline 3 & Victory-1 & 200 & 0.00 & 0.00 & 0.08 & 3.95 & 7.11 & 9.48 & 10.27 & 12.64 & 14.22 & 15.01 & 18.17 & 32.68 & 67.32 & 3269.6 \\
\hline 4 & Victory-1 & 240 & 0.00 & 0.00 & 0.08 & 5.60 & 9.60 & 12.00 & 15.20 & 16.00 & 18.40 & 20.80 & 23.20 & 41.73 & 58.27 & 2587.4 \\
\hline 5 & Victory-1 & 300 & 0.00 & 0.00 & 0.16 & 5.77 & 7.96 & 10.61 & 12.25 & 12.87 & 14.20 & 15.91 & 17.16 & 30.86 & 69.14 & 3566.0 \\
\hline
\end{tabular}

Table 3

Results of study of kinetics of approximate and specified effective dosage of Victory-2 demulsifier at $90{ }^{\circ} \mathrm{C}$ of test temperature

\begin{tabular}{|c|c|c|c|c|c|c|c|c|c|c|c|c|c|c|c|c|}
\hline \multirow[b]{3}{*}{ No } & \multirow[b]{3}{*}{ Product } & \multirow{3}{*}{ 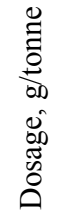 } & \multicolumn{11}{|c|}{ Amount of water released, \% } & \multirow{3}{*}{ 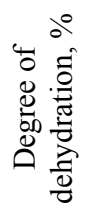 } & \multirow{3}{*}{ 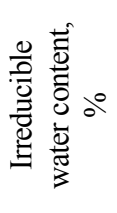 } & \multirow{3}{*}{ 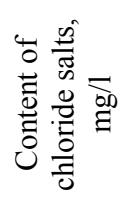 } \\
\hline & & & \multicolumn{11}{|c|}{ Time, $\min$} & & & \\
\hline & & & 5 & 10 & 15 & 20 & 30 & 40 & 50 & 60 & 75 & 90 & 120 & & & \\
\hline \multicolumn{17}{|c|}{ Estimated effectiveness, a value of bound water is $54 \%$} \\
\hline 1 & Dummy sample & 0 & 0.00 & 0.00 & 0.00 & 0.00 & 0.00 & 0.00 & 0.00 & 0.00 & 0.80 & 1.60 & 2.40 & 4.44 & 95.56 & 7118.3 \\
\hline 2 & Victory-2 & 150 & 0.00 & 0.00 & 2.31 & 6.16 & 8.47 & 18.48 & 24.64 & 27.72 & 30.03 & 30.80 & 31.57 & 58.46 & 41.54 & 2245.6 \\
\hline 3 & Victory-2 & 200 & 0.00 & 0.00 & 3.16 & 7.90 & 18.96 & 26.07 & 30.02 & 30.81 & 31.60 & 32.39 & 32.39 & 59.98 & 40.02 & 2141.3 \\
\hline 4 & Victory-2 & 240 & 0.00 & 0.00 & 2.34 & 7.80 & 13.26 & 26.52 & 29.64 & 30.42 & 31.20 & 31.98 & 32.76 & 60.67 & 39.33 & 2099.8 \\
\hline 5 & Victory-2 & 300 & 0.00 & 0.00 & 2.46 & 9.84 & 22.14 & 28.70 & 30.34 & 31.98 & 33.62 & 34.44 & 34.44 & 63.78 & 36.22 & 2038.8 \\
\hline \multicolumn{17}{|c|}{ Specified effectiveness, a value of bound water is $42 \%$} \\
\hline 1 & Dummy sample & 0 & 0.00 & 0.00 & 0.00 & 0.00 & 0.00 & 0.80 & 0.80 & 0.80 & 1.20 & 1.60 & 2.40 & 5.71 & 94.29 & 5940.9 \\
\hline 2 & Victory-2 & 220 & 0.00 & 7.20 & 11.20 & 13.60 & 16.00 & 19.20 & 20.00 & 20.80 & 21.60 & 21.60 & 22.40 & 53.33 & 46.67 & 2120.7 \\
\hline 3 & Victory-2 & 260 & 0.00 & 6.56 & 9.84 & 13.94 & 16.40 & 18.86 & 19.68 & 21.32 & 21.32 & 22.14 & 22.14 & 52.71 & 47.29 & 2778.5 \\
\hline
\end{tabular}


Table 4

Results of study of kinetics of approximate and specified effective dosage of Victory-3 demulsifier at $90{ }^{\circ} \mathrm{C}$ of test temperature

\begin{tabular}{|c|c|c|c|c|c|c|c|c|c|c|c|c|c|c|c|c|}
\hline \multirow{3}{*}{ No } & \multirow{3}{*}{ Product } & \multirow{3}{*}{ 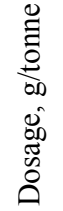 } & \multicolumn{11}{|c|}{ Amount of water released, \% } & \multirow{3}{*}{ 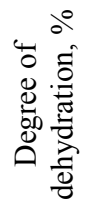 } & \multirow{3}{*}{ 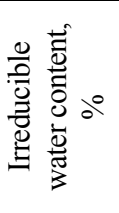 } & \multirow{3}{*}{ 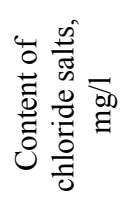 } \\
\hline & & & \multicolumn{11}{|c|}{ Time, $\min$} & & & \\
\hline & & & 5 & 10 & 15 & 20 & 30 & 40 & 50 & 60 & 75 & 90 & 120 & & & \\
\hline \multicolumn{17}{|c|}{ Estimated effectiveness, a value of bound water is $44 \%$} \\
\hline 1 & Dummy sample & 0 & 0.00 & 0.00 & 0.16 & 2.40 & 3.20 & 4.00 & 4.80 & 4.80 & 5.60 & 6.40 & 7.20 & 16.36 & 83.64 & 6749.2 \\
\hline 2 & Victory-3 & 150 & 0.08 & 4.74 & 8.69 & 11.85 & 15.01 & 21.33 & 22.91 & 25.28 & 26.07 & 26.07 & 26.07 & 59.25 & 40.75 & 2457.0 \\
\hline 3 & Victory-3 & 200 & 0.00 & 2.46 & 5.74 & 9.84 & 13.94 & 20.50 & 22.14 & 24.60 & 24.60 & 25.42 & 26.24 & 59.64 & 40.36 & 2367.0 \\
\hline 4 & Victo & 240 & 0.16 & 4.00 & 7.20 & 10.40 & 15.20 & 18.40 & 21.60 & 24.00 & 24.80 & 25.60 & 26.4 & 60.00 & 40.00 & 1109.7 \\
\hline 5 & Victory-3 & 300 & 0.04 & 3.28 & 7.38 & 11.48 & 17.22 & 23.78 & 27.06 & 27.88 & 28.70 & 28.70 & 29.52 & 67.09 & 32.91 & 725.0 \\
\hline \multicolumn{17}{|c|}{ Specified effectiveness, a value of bound water is $42 \%$} \\
\hline 1 & Dummy sar & 0 & 0.00 & 0.00 & 0.00 & 0.00 & 0.00 & 0.80 & 0.80 & 0.80 & 1.20 & 1.60 & 2.40 & 5.71 & 94.29 & 5940.9 \\
\hline 2 & Victory-3 & 220 & 0.00 & 7.20 & 13.60 & 16.80 & 20.80 & 22.40 & 23.20 & 24.00 & 24.00 & 24.00 & 24.00 & 57.14 & 42.86 & 1556.2 \\
\hline 3 & Victory-3 & 260 & 0.00 & 8.20 & 13.94 & 16.40 & 21.32 & 23.78 & 23.78 & 24.60 & 25.42 & 25.42 & 25.42 & 60.52 & 39.48 & 1093.4 \\
\hline
\end{tabular}

Table 5

Results of study of kinetics of approximate and specified effective dosage of Rauan-2050 demulsifier at $90{ }^{\circ} \mathrm{C}$ of test temperature (a value of bound water is $42 \%$ )

\begin{tabular}{|c|c|c|c|c|c|c|c|c|c|c|c|c|c|c|c|c|}
\hline \multirow{3}{*}{ No } & \multirow{3}{*}{ Product } & \multirow{3}{*}{ 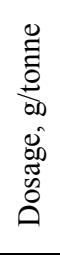 } & \multirow{2}{*}{\multicolumn{11}{|c|}{ Amount of water released, \% }} & \multirow{3}{*}{ 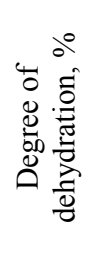 } & \multirow{3}{*}{ 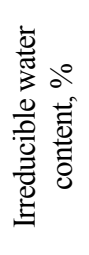 } & \multirow{3}{*}{ 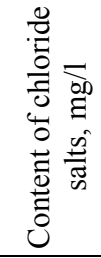 } \\
\hline & & & & & & \multicolumn{7}{|c|}{ Time, $\min$} & & & & \\
\hline & & & 5 & 10 & 15 & 20 & 30 & 40 & 50 & 60 & 75 & 90 & 120 & & & \\
\hline 1 & Dummy sample & 0 & 0.00 & 0.00 & 0.00 & 0.00 & 0.00 & 0.80 & 0.80 & 0.80 & 1.20 & 1.60 & 2.40 & 5.71 & 94.29 & 5940.9 \\
\hline 2 & Rauan-2050 & 100 & 0.00 & 2.40 & 5.60 & 9.60 & 12.00 & 13.60 & 15.20 & 15.20 & 16.00 & 16.80 & 17.60 & 41.90 & 58.10 & 3626.3 \\
\hline 3 & Rauan-2050 & 150 & 0.00 & 4.00 & 8.00 & 9.60 & 12.80 & 14.40 & 16.80 & 17.60 & 17.60 & 18.40 & 19.20 & 45.71 & 54.29 & 3231.4 \\
\hline 4 & Rauan-2050 & 200 & 0.00 & 8.00 & 12.00 & 13.60 & 16.80 & 20.00 & 21.60 & 22.40 & 23.20 & 24.00 & 24.80 & 59.05 & 40.95 & 2650.1 \\
\hline 5 & Rauan-2050 & 220 & 0.00 & 7.20 & 8.80 & 12.00 & 16.80 & 20.00 & 20.80 & 22.40 & 23.20 & 24.00 & 24.80 & 59.05 & 40.95 & 1154.7 \\
\hline 6 & Rauan-2050 & 240 & 0.00 & 7.29 & 9.72 & 12.96 & 18.63 & 21.06 & 21.87 & 23.49 & 25.11 & 25.11 & 25.92 & 61.71 & 38.29 & 709.8 \\
\hline 7 & Rauan-2050 & 260 & 0.00 & 5.67 & 8.10 & 12.15 & 17.82 & 20.25 & 21.12 & 22.64 & 24.14 & 25.10 & 25.10 & 59.76 & 40.24 & 1007.6 \\
\hline 8 & Rauan-2050 & 300 & 0.00 & 8.10 & 11.34 & 15.39 & 20.25 & 21.68 & 22.30 & 23.11 & 23.98 & 24.72 & 24.72 & 58.86 & 41.14 & 1105.3 \\
\hline
\end{tabular}

dehydration level of $30.86 \%$, residual water content in oil is $69.14 \%$. The content of chloride salts in oil is decreased from 5.94 to $3.57 \mathrm{~g} / \mathrm{l}$. When a demulsifier is added into a water-oil emulsion released water does not get cloudy, there is no clear interface and intermediate layer, no precipitation formed, but there is adhesion to test tube walls.

As a result of evaluation of effectiveness of Victory demulsifiers Victory-2 and Victory-3 were chosen to clarify the optimal effective dosage during futher studies.

There is a decrease in content of chloride salts in doses of 240 and $300 \mathrm{~g} /$ tonne in more that 3 times (from 7.12 to $2.04 \mathrm{~g} / \mathrm{l}$ ) if Victory-2 demulsifier is added to oil emulsion (Table 3 and
Fig. 4). At the same time, degree of dehydration reaches a maximum value at $300 \mathrm{~g} /$ tonne and is $63.78 \%$, while the same effect is achieved using $240 \mathrm{~g} / \mathrm{t}$ of the base agent. Released (separated) water does not cloud, there is a clear interface between the phases, no intermediate layer and no sediment is formed. Adhesion to the test tube walls is not established.

Results of Victory-3 demulsifier, presented in Table 4 and Fig. 5, show that there is a significant reduction in chloride salts down to $0.73 \mathrm{~g} / 1$ is observed if the demulsifier is added into a water-oil emulsion. In comaprison with two other demulsifiers (Victory-1 and 2) of the same product line Victory-3 demulsifier is more effective at dosage of $300 \mathrm{~g} / \mathrm{t}$, dehydration level reaches a maximum value of 

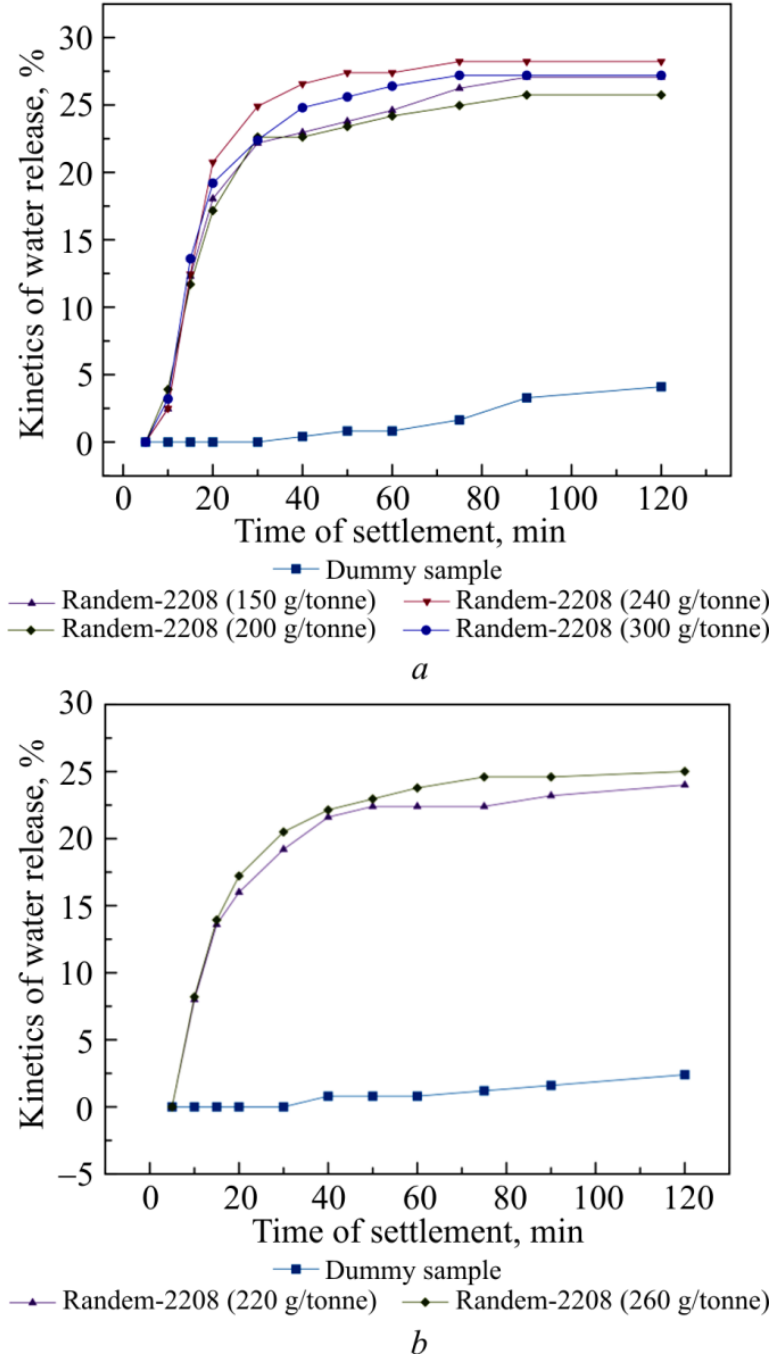

Fig. 2. Kinetics of water release in presence of Randem-2208 demulsifier at bound water values of $44.6 \%(a)$ and $42 \%(b)$ (see Table 1$)$

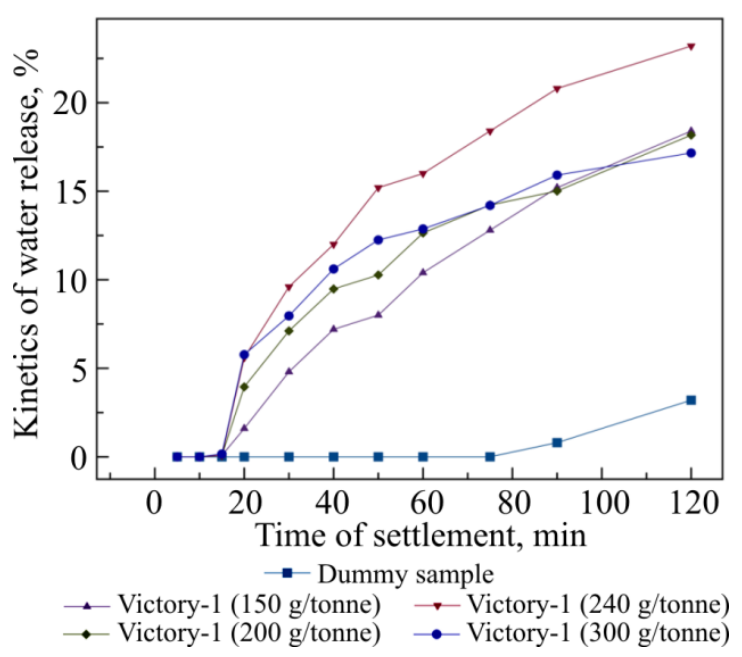

Fig. 3. Kinetics of water release in presence of Victory-1 demulsifier
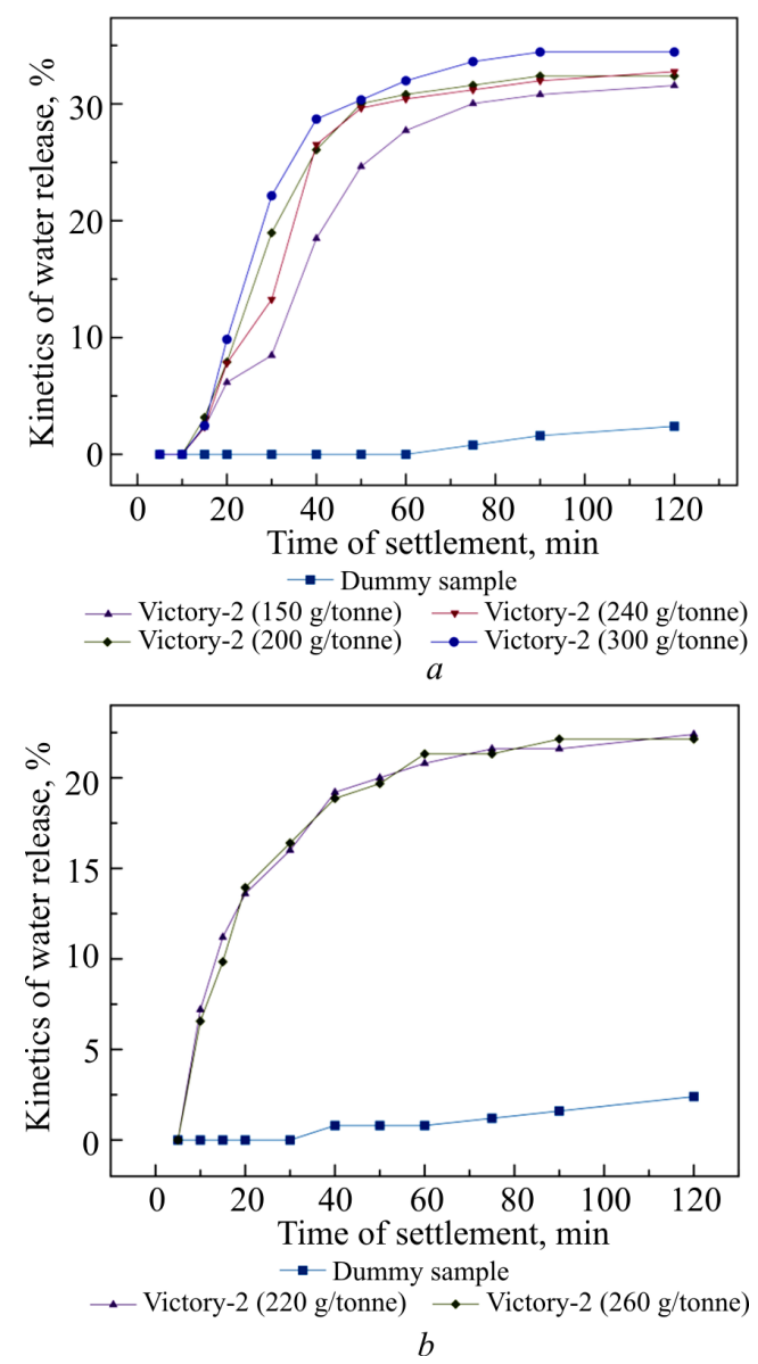

Fig. 4. Kinetics of water release in presence of Victory-2 demulsifier at bound water values of $54 \%(a)$ and $52 \%(b)$ (see Table 3 )

$67.9 \%$. In comparison with the basic demulsifier Randem-2208 Victory-3 does not provide sufficient good dehydration at a specific consumption of $240 \mathrm{~g} / \mathrm{t}$. Water released does not cloud if demulsifier is added into the water-oil emulsion. There is a clear interface between the phases, no intermediate layer, no adhesion on test tube walls, but there is a small amount of precipitatation.

There are results of study of kinetics of approximate and specified effective dosage of the demulsifier Rauan-2050 presened in Table 5 and in Fig. 6. In case if the demulsifier is added into the water-oil emulsion then a degree of dehydration at specific rates of 240 and $300 \mathrm{~g} /$ tonne was $61.7 \%$, irreducible water saturation in oil was $38.29 \%$. Released water does not cloud, there is a clear 

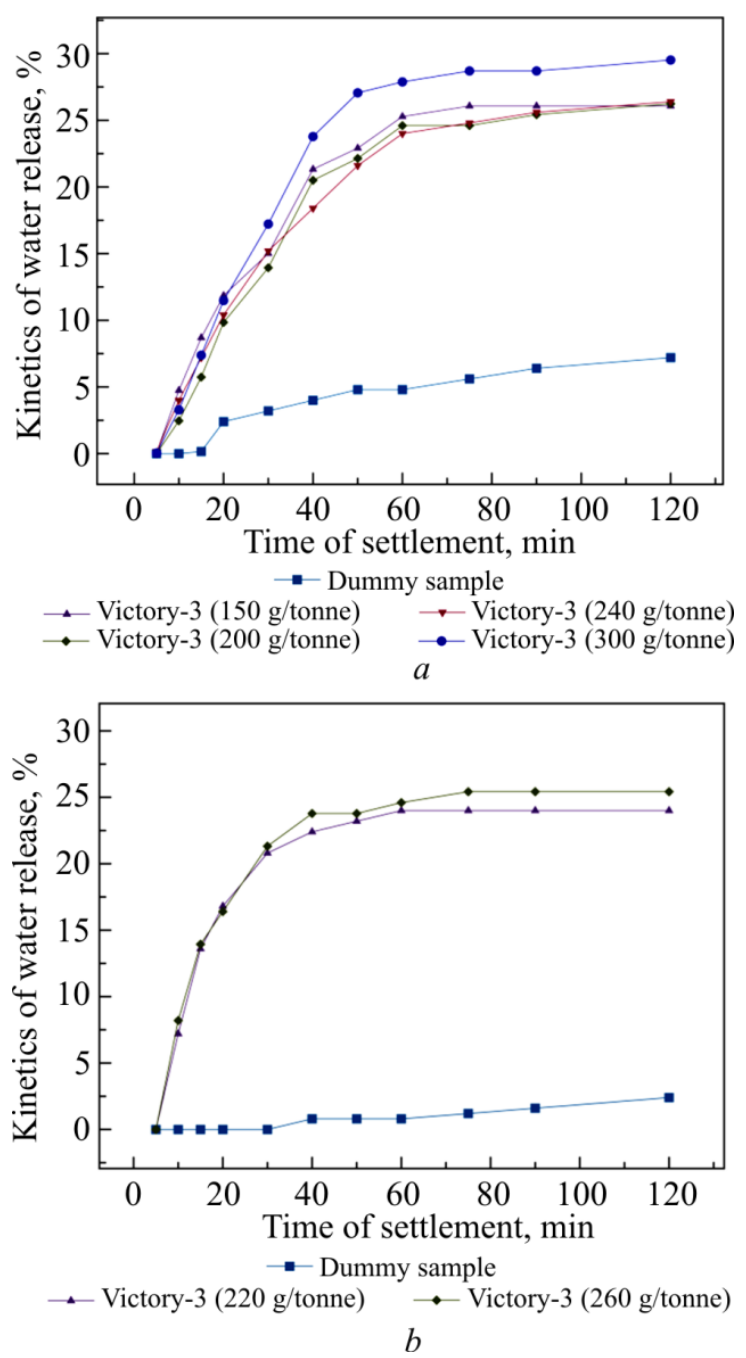

Fig. 5. Kinetics of water release in presence of Victory-3 demulsifier at bound water values of $44 \%(a)$ and $42 \%(b)$ (see Table 4 )

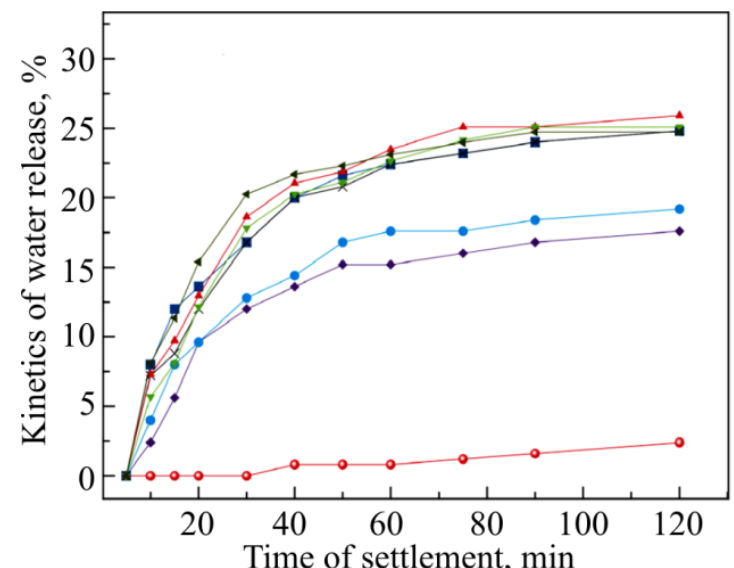

$\therefore$ Dummy sample $\quad \rightarrow$ Rauan-2050 (220 g/tonne

$\rightarrow$ Rauan-2050 (100 g/tonne) $\rightarrow$ Rauan-2050 (240 g/tonne)

$\rightarrow$ Rauan-2050 (150 g/tonne) $\rightarrow$ Rauan-2050 (260 g/tonne)

- Rauan-2050 (200 g/tonne) —Rauan-2050 (300 g/tonne)

Fig. 6. Kinetics of water release in presence of Rauan-2050 demulsifier

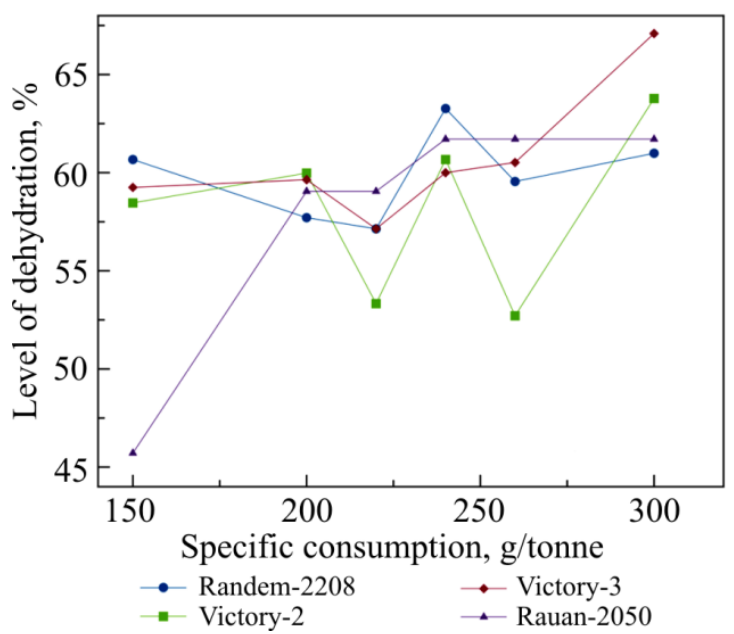

Fig. 7. Function of a level of dehydration versus specific consumption of Randem-2208, Victory-2, 3 and Rauan-2050 demulsifiers

interface between the phases, no intermediate layer, no precipitation forms and adhesion to test tube walls is not established.

There are the same (stable) results in level of dehydration and irreducible water saturation at 240, 260 and $300 \mathrm{~g} /$ tonne for Rauan-2050 demulsifier. At the same time the content of chloride salts in oil decreases by an order of magnitude from 5.94 to $0.71 \mathrm{~g} / 1$, which is also an indicator of quality of oil treatment.

\section{Conclusion}

Analysis of results of laboratory studies (Fig. 7) shows that according to the level of dehydration at technological specific consumption of $240 \mathrm{~g} /$ tonne all the test chemicals are inferior to the basic agentdemulsifier Randem-2208. In terms of desalting properties the base demulsifier are inferior to demulsifiers Victory-2, 3 and Rauan-2050.

Thus, an analysis of results of laboratory tests showed the following:

1. The demulsifier Victory-1 does not show high demulsibility in comparison with the base and other demulsifying agents.

2. The demulsifier Victory-2 compared to the basic demulsifier Randem-2208 with technological specific consumption of $240 \mathrm{~g} /$ tonne showed the lowest demulsifying ability, level of dehydration is $60.67 \%$.

3. The demulsifier Victory-3 in comparison with the basic demulsifier Randem-2208 provides quite 
good dehydration and desaltation of water-oil emulsion at specific consumption of $220-300 \mathrm{~g} /$ tonne.

4. The demulsifier Rauan-2050 in comparison with the basic demulsifier Randem-2208 shows a good demulsifying ability. It has stable results on residual water content in oil and significantly reduces content of chloride salts in oil at specific rates of 220-300 g/tonne. But if the concentration is $240 \mathrm{~g}$ /tonne (field one), Randem-2208 has the best demulsifying ability.

Analysis of stability of oil emulsions performed depending on watercut and consumption indicators of agent-demulsifier that provide their stratification, showed that the effectiveness of demulsification is affected by interaction of two factors such as the content of water phase and level of its dispersion. Since oil demulsification using agent-demulsifier is associated with destruction and adsorption displacement by demulsifier of natural stabilizers from the oil-water interface, an increase in water content has a strong effect on agent consumption.

Thus, results of conducted experimental studies show that the higher the water content in oil the lower the consumption of an agent-demulsifier. At the same time, it is possible to reduce demulsifier consumption several times with no reduce in efficiency of oil dehydration through deliberately increase in water saturation of treated complex in rheology oil to its ultimate value.

\section{References}

1. Aliev R.A., Belousov B.D., Nemudrov A.G. et al. Truboprovodnyi transport nefti i gaza [Pipeline transportation of oil and gas]. Moscow, Nedra, 1988, 368 p.

2. Antipin Iu.V., Valeev M.D., Syrtlanov A.Sh. Predotvrashchenie oslozhnenii pri dobyche obvodnennoi nefti [Prevention of complications in the production of watered oil]. Ufa, Bashkortostan, 1987, 168 p.

3. Akhmetov A.T., Telin A.G., Kornilov A.A. Dispersionnye i reologicheskie kharakteristiki obratnykh vodoneftianykh emul'sii na osnove neftei [Dispersion and rheological characteristics of reverse water-oil emulsions based on oils]. Nauchno-tekhnicheskii vestnik IuKOS, 2004, no. 9, pp.43-50.

4. Akhmetov R.A., Bleikher E.M. Truboprovodnyi transport vysokoviazkikh neftei $\mathrm{s}$ zhidkimi uglevodorodnymi razbaviteliami [Pipeline transportation of high-viscosity oils with liquid hydrocarbon diluents]. Transport $i$ khranenie nefti $i$ nefteproduktov. Moscow, TNTO, 1970, $52 \mathrm{p}$.

5. Akhmetov R.M., Livanov Iu.V. Dispetcherizatsiia i uchet na nefteprovodakh [Dispatching and accounting at oil pipelines]. Moscow, Nedra, 1976, $351 \mathrm{p}$.

6. Bagirov M.K., Bagirov O.T., Ramazanova F.A., Kelova I.N. Stimulirovanie svoistv reagentov fizicheskimi poliami v protsesse deemul'satsii neftei [Stimulation of the properties of reagents by physical fields during the demulsification of oils]. Protsessy neftekhimii $i$ neftepererabotki. Baku, 2002, 1 (8), pp.19-22.

7. Baikov N.M., Pozdnyshev G.N., Mansurov R.I. Sbor i promyslovaia podgotovka nefti, gaza i vody [Collection and field preparation of oil, gas and water]. Moscow, Nedra, 1981, 261 p.

8. Vasil'ev G.G. et al. Truboprovodnyi transport nefti [Pipeline transportation of oil]. Moscow, Nedra, 2002, vol.1, $361 \mathrm{p}$.
9. Svarofskaia N.A. Podgotovka, transport i khranenie skvazhinnoi produktsii [Preparation, transportation and storage of well production]. Tomsk, Izdatel'stvo Tomskogo politekhnicheskogo universiteta, 2004, 268 p.

10. Serkebaeva S.B. Osobennosti reologii vodnoneftianykh emul'sii [Features of rheology of water-oil emulsions]. Neftepromyslovoe delo, 2015, no. 1.

11. Promyslovoi sbor i podgotovka anomal'nykh neftei [Field gathering and treatment of anomalous oil]. Sbornik nauchnykh trudov VNIISPTneft'. Ufa, 1986, 137 p.

12. Zhuiko P.V. Razrabotka printsipov upravleniia reologicheskimi svoistvami anomal'nykh neftei [Development of principles for controlling the rheological properties of anomalous oils]. Abstract of Doctor's degree dissertation. Ukhta, 2003, 43 p.

13. Nurmammedov R.G., Ismaiylov G.G. Ob izmenenii pokazatelei kachestve neftei pri ikh smeshivanii [On the change in indicators of the quality of oils when they are mixed]. Vestnik Kazakhstansko-Britanskogo tekhnicheskogo universiteta, 2013, no.1 (24), pp.19-27.

14. Serkebaeva B.S., Myrzagalieva K.N. Optimizatsiia tekhnologii primeneniia deemul'gatorov [Optimization of the technology of demulsifying agents]. Neft' $i$ gaz. Moscow, 2015, vol.1, p.391.

15. Levchenko D.N., Bergshtein N.V., Khudakova A.D., Nikolaeva N.M. Emul'sii nefti s vodoi i metody ikh razrusheniia [Emulsions of oil and water and methods of their destruction]. Moscow, Energoizdat, 1987, $464 \mathrm{p}$.

16. Vasil'ev G.G., Korobkov G.E., Korshak A.A., Shammazov A.M. Truboprovodnyi transport nefti [Pipeline transportation of oil]. Ed. M.S. Vainshtok. Moscow, Nedra-Biznestsentr, 2002, vol.1, 497 p.

17. Neftegazovoe delo [Oil and gas business], available at: http://www.ogbus.ru (accessed: 13 January 2017). 
18. Tronov V.P. Promyslovaia podgotovka nefti [Commercial oil preparation]. Moscow, Nedra, 1977, 260 p.

19. Pal R. Techniques for measuring composition (oil and water content) of emulsions. Colloids \& Surfaces, 1994, no.84, pp.141-193. DOI: 10.1016/0927-7757(93)02711-M

20. Water-in-crude oil emulsions from the Norwegian continental shelf. Part II. Chemical destabilization and interfacial tensions. Colloid and Polymer Science, 1990, vol.268, no.4, pp.389-398. DOI:10.1007/BF01411682

21. Mason T.G., Graves S.M., Wilking J.N., Lim M.Y. Effective structure factor of osmotically deformed nanoemulsions. Journal of Physical Chemistry B, 2006, vol.110, pp.22097-22102. DOI: 10.1021/jp0601623

22. Berli C.L.A. Rheology and phase behavior of aggregating emulsions related to droplet-droplet interactions. Brazilian Journal of Chemical Engineering, 2007, vol. 24, pp.203-210. DOI: 10.1590/S0104-66322007000200005

23. Oliveira R.C.G., Goncalves M.A.L. Emulsion rheology - theory vs. field observation. Proc. Offshore Technology Conference. Houston, 2005, OTC Paper 17386.

24. Nour A.H., Yunus R.M. Stability investigation of water-in-crude oil Emulsion. Journal of Applied Sciences, 2006, vol. 6, pp.2895-2900. DOI: 10.3923/jas.2006.2895.2900

25. Coussot P., Tocquer L., Lanos C., Ovarlez G. Macroscopic vs. local rheology of yield stress fluids. Journal of Non-Newtonian Fluid Mechanics, 2009, vol.158, no.1-3, pp.85-90. DOI: 10.1016/j.jnnfm.2008.08.003
26. Ismaiylov G.G., Safarov N.M., Gasanov Kh.I. O perspektivakh i tselesoobraznosti primeneniia tekhnologii gidrotransporta $\mathrm{v}$ Azerbaidzhane [About prospects and expediency of application of hydro transport technologies in Azerbaijan]. Materialy mezhdunarodnogo tekhnicheskogo simpoziuma «Truboprovodnyi transport2011». Moscow, 2011, pp.19-24.

27. Ismaiylov G.G., Safarov N.M., Kelova I.N. $\mathrm{O}$ novom podkhode $\mathrm{k}$ strukturno-reologicheskim svoistvam vodoneftianykh emul'sii [On a new approach to the structural and rheological properties of water-oil emulsions]. Vestnik Azerbaidzhanskoi inzhenernoi akademii, 2011, vol.3, no.2, pp.81-94.

28. Gumbatov G.G. Izuchenie protsessa sbora, transporta i podgotovki neftei $\mathrm{v}$ usloviiakh morskikh mestorozhdenii Azerbaidzhana [Study of the process of collecting, transporting and preparing oil in the conditions of the offshore fields of Azerbaijan]. Baku, El'm, 1996, 240 p.

29. GOST 14870-77. Produkty khimicheskie. Metody opredeleniia vody [Chemical products. Methods for determination of water]. Moscow, Izdatel'stvo standartov, $1977,14 \mathrm{p}$.

30. GOST 21534-76. Metody opredeleniia soderzhaniia khloristykh solei [Methods for determining the content of chloride salts]. Moscow, Izdatel'stvo standartov, 1976, $17 \mathrm{p}$.

\section{Библиографический список}

1. Трубопроводный транспорт нефти и газа: учеб. для вузов / Р.А. Алиев, Б.Д. Белоусов, А.Г. Немудров [и др.]. - М.: Недра, 1988. - 368 с.

2. Антипин Ю.В., Валеев М.Д., Сыртланов А.Ш. Предотвращение осложнений при добыче обводненной нефти. - Уфа: Башкортостан, 1987. - 168 с.

3. Ахметов А.Т., Телин А.Г., Корнилов А.А. Дисперсионные и реологические характеристики обратных водонефтяных эмульсий на основе нефтей // Научно-технический вестник ЮКОС. - 2004. - № 9. C. $43-50$.

4. Ахметов Р.А., Блейхер Э.М. Трубопроводный транспорт высоковязких нефтей с жидкими углеводородными разбавителями // Транспорт и хранение нефти и нефтепродуктов. - М.: ТНТО, 1970. - 52 с.

5. Ахметов Р.М., Ливанов Ю.В. Диспетчеризация и учет на нефтепроводах. - М.: Недра, 1976. - 351 с.

6. Стимулирование свойств реагентов физическими полями в процессе деэмульсации нефтей / М.К. Багиров, О.Т. Багиров, Ф.А. Рамазанова, И.Н. Келова // Процессы нефтехимии и нефтепереработки. - 2002. - 1 (8). - С. 19-22.

7. Байков Н.М., Позднышев Г.Н., Мансуров Р.И. Сбор и промысловая подготовка нефти, газа и воды. М.: Недра, 1981. - 261 с.
8. Трубопроводный транспорт нефти / Г.Г. Васильев [и др.]. - М.: Недра, 2002. - Т. 1. - 361 с.

9. Сварофская Н.А. Подготовка, транспорт и хранение скважинной продукции. - Томск: Изд-во Томск. политехн. ун-та, 2004. - 268 с.

10. Серкебаева С.Б. Особенности реологии воднонефтяных эмульсий // Нефтепромысловое дело. 2015. - № 1 .

11. Промысловой сбор и подготовка аномальных нефтей: сб. науч. тр. ВНИИСПТнефть. - Уфа, 1986. - 137 с.

12. Жуйко П.В. Разработка принципов управления реологическими свойствами аномальных нефтей: автореф. дис. ... д-ра техн. наук. - Ухта, 2003. - 43 с.

13. Нурмаммедов Р.Г., Исмайылов Г.Г. Об изменении показателей качества нефтей при их смешивании // Вестник Казахстанско-Британского технического университета. - 2013. - № 1 (24). C. $19-27$.

14. Серкебаева Б.С., Мырзагалиева К.Н. Оптимизация технологии применения деэмульгаторов // Нефть и газ: сб. тез. - М., 2015. - Т. 1. - С. 391.

15. Эмульсии нефти с водой и методы их разрушения / Д.Н. Левченко, Н.В. Бергштейн, А.Д. Худакова, Н.М. Николаева - М.: Энергоиздат, 1987. - 464 c. 
16. Трубопроводный транспорт нефти / Г.Г. Васильев, Г.Е. Коробков, А.А. Коршак, А.М. Шаммазов; под ред. М.С. Вайнштока. - М.: Недра-Бизнесцентр, 2002. - Т. 1. - 497 с.

17. Нефтегазовое дело [Электронный научный журнал]. - URL: http://www.ogbus.ru (дата обращения: 13.01.2017).

18. Тронов В.П. Промысловая подготовка нефти. М.: Недра, 1977. - 260 с.

19. Pal R. Techniques for measuring composition (oil and water content) of emulsions // Colloids \& Surfaces. - 1994. № 84. - P. 141-193. DOI: 10.1016/0927-7757(93)02711-M

20. Water-in-crude oil emulsions from the Norwegian continental shelf. Part II. Chemical destabilization and interfacial tensions // Colloid and Polymer Science. - 1990. Vol. 268, № 4. - P. 389-398. DOI: 10.1007/BF01411682

21. Effective structure factor of osmotically deformed nanoemulsions / T.G. Mason, S.M. Graves, J.N. Wilking, M.Y. Lim // Journal of Physical Chemistry B. - 2006. Vol. 110. - P. 22097-22102. DOI: 10.1021/jp0601623

22. Berli C.L.A. Rheology and phase behavior of aggregating emulsions related to droplet-droplet interactions // Brazilian Journal of Chemical Engineering. - 2007. - Vol. 24. - P. 203-210. DOI: $10.1590 / \mathrm{S} 0104-66322007000200005$

23. Oliveira R.C.G., Goncalves M.A.L. Emulsion rheology - theory vs. field observation // Proc. Offshore Technology Conference. - Houston, Texas, 2005. OTC Paper 17386.
24. Nour A.H., Yunus R.M. Stability investigation of water-in-crude oil Emulsion // Journal of Applied Sciences. - 2006. - Vol. 6. - P. 2895-2900. DOI: $10.3923 /$ jas.2006.2895.2900

25. Macroscopic vs. local rheology of yield stress fluids / P. Coussot, L. Tocquer, C. Lanos, G. Ovarlez // Journal of Non-Newtonian Fluid Mechanics. 2009. - Vol. 158, № 1-3. - P. 85-90. DOI: $10.1016 /$ j.jnnfm.2008.08.003

26. Исмайылов Г.Г., Сафаров Н.М., Гасанов Х.И. О перспективах и целесообразности применения технологий гидротранспорта в Азербайджане // Трубопроводный транспорт - 2011: материалы междунар. техн. симп. - М., 2011. - С. 19-24.

27. Исмайылов Г.Г., Сафаров Н.М., Келова И.Н. О новом подходе к структурно-реологическим свойствам водонефтяных эмульсий // Вестник Азербайджанской инженерной академии. - 2011. T. 3, № 2. - С. 81-94.

28. Гумбатов Г.Г. Изучение процесса сбора, транспорта и подготовки нефтей в условиях морских месторождений Азербайджана. - Баку: Эльм, 1996. -240 c.

29. ГОСТ 14870-77. Продукты химические. Методы определения воды. - М.: Изд-во стандартов, 1977. - 14 c.

30. ГОСТ 21534-76. Методы определения содержания хлористых солей. - М.: Изд-во стандартов, 1976. - 17 c.

Please cite this article in English as:

Ismaiylov G.G., Izbasarov E.I., Adygezalova M.B., Khalilov R.Z. Study of influence of demulsifiers on complex in rheology oil dehydration kinetics. Perm Journal of Petroleum and Mining Engineering, 2017, vol.16, no.2, pp.138-147. DOI: $10.15593 / 2224-9923 / 2017.2 .4$

Просьба ссылаться на эту статью в русскоязычных источниках следующим образом:

Исследование влияния реагентов-деэмульгаторов на кинетику обезвоживания реологически сложной нефти / Г.Г. Исмайылов, Е.И. Избасаров, М.Б. Адыгезалова, Р.З. Халилов // Вестник Пермского национального исследовательского политехнического университета. Геология. Нефтегазовое и горное дело. - 2017. - Т.16, №2. - C.138-147. DOI: 10.15593/2224-9923/2017.2.4 